\title{
EFEKTIVITAS VIRTUAL TICKER TIMER UNTUK MENINGKATKAN PEMAHAMAN PESERTA DIDIK MATERI GRAFIK GERAK LURUS MENGGUNAKAN MODEL POE2WE
}

\author{
Imiftah Nurnazarudin ${ }^{1)}$, Sovi Ayudia Syahfi' ${ }^{2}$, Ina Rostiana ${ }^{3)}$, Nana $^{4)}$ \\ Program Pendidikan Fisika Fakultas Keguruan dan Ilmu Pendidikan \\ Universitas Siliwangi \\ Jln. Siliwangi No.24 Tasikmalaya \\ E-mail : imiftahnur@gmail.com,nana@unsil.ac.id
}

\begin{abstract}
Fisika merupakan bagian dari sains yang memahami segala sesuatu tentang gejala-gejala alam yang terjadi. Banyak sekali fakta di sekolah-sekolah bahwa pelajaran fisika merupakan pelajaran yang sulit dipahami dan membosankan. Konsep dan rumus yang telah disampaikan oleh guru biasanya hanya digunakan dalam penyelesaian soal-soal saja dan siswa cenderung bosan dan sulit untuk memahami konsep tersebut. Sehingga diperlukan media untuk membantu proses belajar-mengajar misalnya media eksperimen. Pada penelitian yang dilakukan, bertujuan untuk : (1) mendeskripsikan simulator gerak lurus beraturan, (2) membutikan pengaruh kecepatan awal terhadap jarak yang ditempuh, (3) menguji efektivitas simulasi gerak lurus beraturan pada percobaan Virtual Ticker Timer, Dalam penyampaian materi pendidik dapat menggunakan model belajar menggunakan model POE2WE (Prediction, Observation, Explanation, Elaboration, Write and Evaluation). Kegiatan penelitian yang dilakukan ini untuk menentukan kecepatan dengan waktu dan jarak maupun perpindahan yang telah ditentukan. Percobaan ini diharapkan dapat membantu peserta didik lebih paham mengenai materi gerak lurus beraturan sehingga dapat memaksimalkan hasil belajar peserta didik. Penelitian ini menggunakan metode penelitian Eksperiment menggunakan Simulator Virtual Ticker Timer dan study pustaka. Hasil penelitian menunjukan bahwa: (1) simulasi virtual ticker timer ini dapat diakses secara mudah , (2) semakin besar kecepatan awal semakin besar juga jarak yang ditempuh, dan (3) simulasi virtual ticker timer ini efektif digunakan sebagai media pembelajaran Fisika di SMA.
\end{abstract}

Key words: Virtual Ticker Timer, Jarak, Waktu, Kecepatan, Model POE2WE.

\begin{abstract}
Abstrak - Physics is a part of science that understands everything about natural phenomena that occur. There are so many facts in schools that physics is difficult to understand and boring. The concepts and formulas that have been submitted by the teacher are usually only used in solving problems and students tend to be bored and difficult to understand the concept. So we need media to help the teaching-learning process, for example, experimental media. In the research carried out, it aims to: (1) describe a straightline motion simulator, (2) prove the effect of the initial velocity on the distance traveled, (3) test the effectiveness of a straight-line motion simulation in the Virtual Ticker Timer experiment, In delivering the material the educator can use learning models using the POE2WE model (Prediction, Observation, Explanation, Elaboration, Write and Evaluation). The research activities carried out to determine the speed with time and distance and the displacement has been determined. This experiment is expected to help students better understand the material of irregular straight motion so as to maximize student learning outcomes. This study uses an Experimental research method using the Virtual Ticker Timer Simulator and literature study. The results showed that: (1) the virtual ticker timer simulation can be accessed easily, (2)
\end{abstract}


the greater the initial speed the greater the distance traveled, and (3) the virtual ticker timer simulation is effectively used as a medium of physics learning in high school.

Kata kunci: Virtual Ticker Timer, Distance, Time, Velocity, Model POE2WE.

I. PENDAHULUAN

Gerak lurus beraturan merupakan salah satu bagian materi dari mekanika. Kebanyakan dari materi gerak lurus peserta didik kurang mampu memahami materi yang dipelajari. Dengan adanya media pembelajaran ini, diharapkan siswa mampu lebih memahami dalam proses belajar mengajar.Pendidik dapat menggunakan Ticker Timer dalam media pembelajaran untuk membantu proses pembelajaran. Ticker timer ini digunakan pada saat pendidik memberikan contoh mengenai materi GLB.

\begin{tabular}{lrr}
\multicolumn{1}{c}{$\begin{array}{c}\text { Menurut } \\
\text { Hadlazim dalam }\end{array}$ Disah, dkk } \\
mengatakan dalam era teknologi, \\
mengetahui & bagaimana & untuk \\
mendapatkan & dan & mengevaluasi \\
informasi dan & bagaimana \\
menggunakannya & untuk memahami \\
dan memecahkan masalah merupakan \\
prasyarat bagi sebagian & besar \\
pekerjaan siswa. Dengan & adanya \\
simulasi virtual & tersebut \\
memudahkan & dalam & proses \\
pembelajaran di kelas & untuk
\end{tabular}

$\begin{aligned} & \text { membuktikan teori } \\ & \text { dikemukakan. }\end{aligned} \begin{array}{r}\text { Mang } \\ \text { ketidakmengertian } \quad \text { siswa }\end{array}$ bisa
disebabkan karena satu hal yaitu
sumber belajar atau media yang
digunakan. Jika media yang
digunakan membosankan, maka akan
kurang memotivasi siswa untuk
belajar. Sedangkan dengan
menggunakan simulasi virtual selain
mudah digunakan dan murah serta
memiliki tampilan yang menarik.

Kurikulum di Indonesia menggunakan kurikulum 2013, dalam kurikulum ini siswa dituntut untuk berperan aktif. Dalam Nana, dkk bahwa pembelajaran kurikulum 2013 adalah pembelajaran kompetensi dengan memperkuat proses pembelajaran dan penilaian autentik untuk mencapai kompetensi sikap, pengetahuan dan keterampilan. Menurut Jauhar (2011) dalam Nana, dkk menyatakan bahwa standar kompetensi untuk bidang sains pada jenjang SMA ditekankan pada kemampuan bekerja ilmiah, dan kemampuan memahami konsepkonsep sains serta penerapannya 
dalam kehidupan. Pratikum secara langsung akan menambah pemahaman siswa, tetapi memerlukan biaya, untuk menekan biaya selama praktikum. Praktikum dapat menggunakan simulasi virtual gerak lurus beraturan.

Gerak lurus beraturan merupakan gerak suatu benda dengan lintasan yang lurus dan memiliki kecepatan yang konstan. Persamaan gerak lurus dapat ditulis secara sistematis sebagai berikut.

$$
\boldsymbol{v}=\frac{d x}{d t}
$$

Dimana $d x$ merupakan perubahan posisi selama selang waktu tertentu (m), dan $d t$ merupakan selang waktu yang ditempuh benda pada saat bergerak (s). dan $\boldsymbol{v}$ adalah kecepatan suatu benda $(\mathrm{m} / \mathrm{s})$. Kecepatan dan percepatan dapat kita tentukan dengan menganggap waktu awal untuk setiap pembahasan adalah nol (0) $t_{1}=0$. Kemudian kita tentukan $t_{2}$ $=\mathrm{t}$ sebagai waktu yang diperlukan. Posisi awal ( $\left.x_{1}\right)$ dan kecepatan awal $\left(v_{1}\right)$ dari sebuah benda sekarang akan dinyatakan dengan $x_{0}$ dan $v_{0}$; dan pada waktu t, posisi dan kecepatan akan disebut $\boldsymbol{x}$ dan $\boldsymbol{v}$ (bukan $x_{2}$ dan $\left.v_{2}\right)$.
Kecepatan rata-rata selama waktu $\mathrm{t}$ akan menjadi :

$$
v=\frac{x-x_{0}}{t}
$$

Karena $\mathrm{t}_{0}=0$. Dan percepatan, yang dianggap konstan terhadap waktu, akan menjadi :

$$
\boldsymbol{a}=\frac{v-v_{0}}{t}
$$

Untuk mengetahui berapa besar kecepatan benda dengan menggunakan alat peraga ticker time dihitung dari jarak tiap titik tiap satuan waktu tertentu. Misalkan , jarak tiap titik adalah $1 \mathrm{~mm}=10^{-3}$, sedangkan frekuensinya adalah $10 \mathrm{~Hz}$, maka waktu yang dibutuhkan tiap titik adalah:

$$
\begin{aligned}
& \mathrm{T}=1 / \mathrm{f}, \mathrm{T}=1 / 10 \mathrm{~Hz} \\
& \mathrm{~T}=0,1 \text { sekon }
\end{aligned}
$$

Maka, kecepatan trolly tersebut adalah

$$
\begin{aligned}
& \mathrm{V}=\frac{s}{t}, \mathrm{~V}=10^{-3} \mathrm{~m} / 0,1 \mathrm{~s} \\
& \mathrm{~V}=10^{-2} \mathrm{~m} / \mathrm{s}
\end{aligned}
$$

Jadi, kecepatan trolly tersebut $10^{-2}$ $\mathrm{m} / \mathrm{s}$.

\section{LANDASAN TEORI}

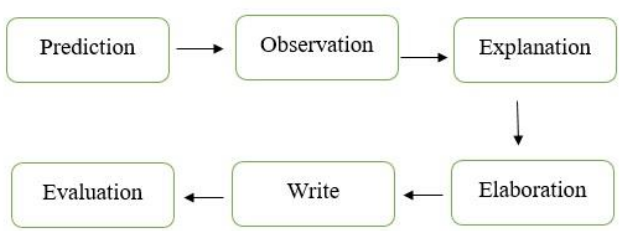

Gambar 1. Sintaks model Pembelajaran POE2WE 
Menurut Nana [1] POE2WE merupakan salah satu model pembelajaran, pendidik dapat melakukan tahapan pada model POE2WE ini, yang pertama "Tahap prediction yaitu siswa membuat prediksi atau dugaan awal terhadap suatu permasalahan. Pendidik dapat mengajukan pertanyaan yang mendorong siswa untuk dapat membuat prediksi atau jawaban sementara dari suatu permasalahan.

Tahap Observation yaitu untuk membuktikan prediksi yang telah di buat oleh siswa. Siswa diajak melakukan eksperimen berkaitan dengan masalah atau persoalan yang di temukan

Tahap Explanation atau menjelaskan yaitu siswa memberikan penjelasan terhadap hasil eksperimen yang telah dilakukan. Tahap elaboration yaitu siswa membuat contoh atau menerapkan konsep dalam kehidupan seharihari. Tahap ini pendidik medorong siswa untuk menerapkan konsep baru dalam situasi baru sehingga siswa lebih memahami konsep yang di ajarkan guru. Tahap ini pengembangan dari pendekatan konstruktivistik. Tahap write atau menulis yaitu melakukan komunikasi secara tertulis,merefleksikan pengetahuan dan gagasan yang dimiliki siswa. Dan yanng terakhir Tahap Evaluation yaitu evaluasi terhadap pengetahuan, keterampilan dan perubahan proses berfikir siswa."

Pada materi gerak lurus, dengan menggunakan virtual ticker timer pendidik dapat menggabungkan model POE2WE. Ticker timer merupakan salah satu alat peraga yang digunakan untuk mempermudah pemahaman peserta didik. Semakin berkembangnya zaman, ticker timer juga ada aplikasinya seperti aplikasi PhET. Pendidik hanya dapat menyediakan dan dapat menggunakan virtual ticker timer ini dengan cara mengatur nilai yang diinginkan.

Untuk mencari jarak dari Gerak Lurus Beraturan, dapat dicari dengan

$$
s=v \cdot t
$$

Pada persaam 4, $s$ (meter) merupakan jarak yang ditempuh, $v(\mathrm{~m} / \mathrm{s})$ merupakan kecepatan yang ditempuh dan $t$ (sekon) merupakan waktu tempuh suatu benda.

\section{METODE PENELITIAN}

Penelitian ini merupakan penelitian experiment atau percobaan. Metode percobaan dilakukan untuk menenukan suatu hipotesis. Seperti yang diungkapkan oleh Sagala (2006: 7-17) dalam Hamid, bahwa : "Eksperimen adalah percobaan untuk membuktikan suatu pertanyaan atau hipotesis tertentu. Eksperimen bisa dilakukan pada suatu laboratorium atau diluar laboratorium, pekerjaan eksperimen mengandung makna belajar untuk berbuat, karena itu dapat dimasukan kedalam metode pembelajaran. Prosedur experiment atau percobaan menggunakan simulasi virtual gerak lurus.

Selain menggunakan metode eksperimen, di penelitian ini menggunakan metode kajian pustaka, yaitu mengkaji berbagai sumber yang bersangkutan dengan 
isi dari penelitian ini. Metode kajian pustaka ini untuk menunjang penelitian ini.

\section{HASIL DAN PEMBAHASAN}

\section{A. Hasil Penelitian}

pada penelitian kali ini kami akan mencoba membandingkan hasal grafik dari percobaan virtual ticker timer dengan hasil grafik dari perhitungan manual.

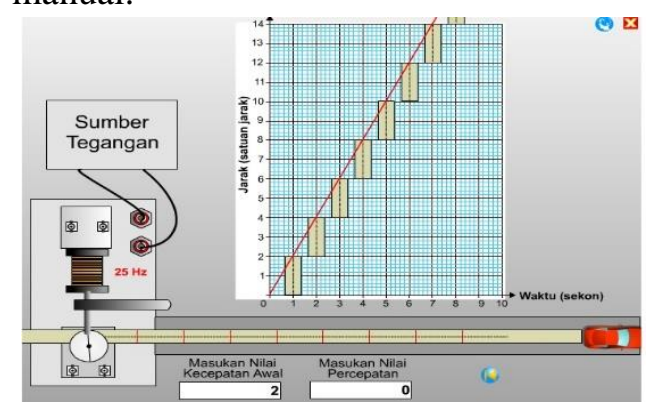

Gambar 2. Grafik jarak terhadap

waktu dengan kecepatan $2 \mathrm{~m} / \mathrm{s}$

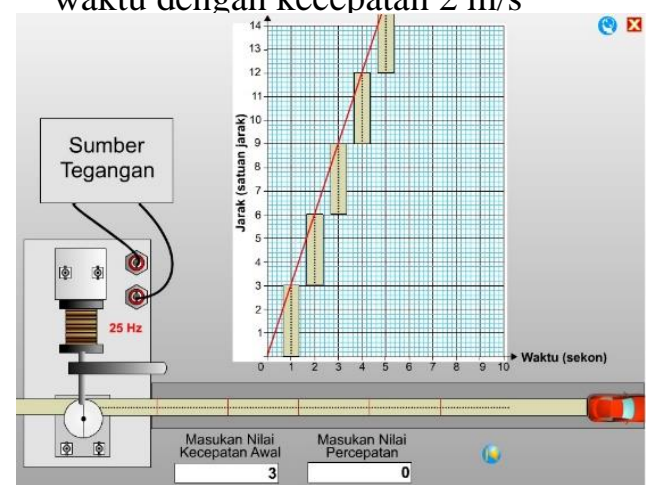

Gambar 3. Grafik jarak terhadap waktu dengan kecepatan $3 \mathrm{~m} / \mathrm{s}$

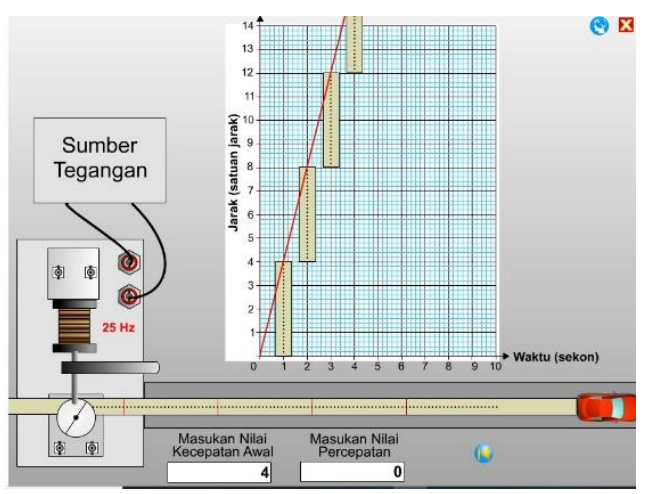

Gambar 4. Grafik jarak terhadap waktu dengan kecepatan $4 \mathrm{~m} / \mathrm{s}$
Grafik di atas adalah contoh percobaan simulasi ticker timer dengan kecepatan $2 \mathrm{~m} / \mathrm{s}, 3 \mathrm{~m} / \mathrm{s}$, dan $4 \mathrm{~m} / \mathrm{s}$. Dengan menggunakan media pembelajaran simulasi ticker timer dalam memahami materi gerak lurus beraturan dapat langsung mengetahui, membedakan dan memahami konsep grafik dari gerak lurus dengan kecepatan dan percepatan yang telah dimasukan sebelumnya.

\section{B. Pembahasan}

Setelah melakukan percobaan di virtual simulator gerak lurus dan mendapatkan hasil grafik dari percobaan tersebut. Kemudian membandingkan hasil percobaan virtual dengan cara perhitungan manual menggunakan rumus.

$$
s=v \cdot t
$$

Sehingga didapatkan hasil seperti pada table 1 dibawah.

\begin{tabular}{|c|c|c|c|}
\hline \multirow{2}{*}{ waktu } & \multicolumn{3}{|c|}{ Kecepatan } \\
\cline { 2 - 4 } & $2 \mathrm{~m} / \mathrm{s}$ & $3 \mathrm{~m} / \mathrm{s}$ & $4 \mathrm{~m} / \mathrm{s}$ \\
\cline { 2 - 4 } & jarak & jarak & Jarak \\
\hline 1 & 2 & 3 & 4 \\
\hline 2 & 4 & 6 & 8 \\
\hline 3 & 6 & 9 & 12 \\
\hline 4 & 8 & 12 & 16 \\
\hline 5 & 10 & 15 & 20 \\
\hline
\end{tabular}

Tabel 1. Hasil perhitungan manual 


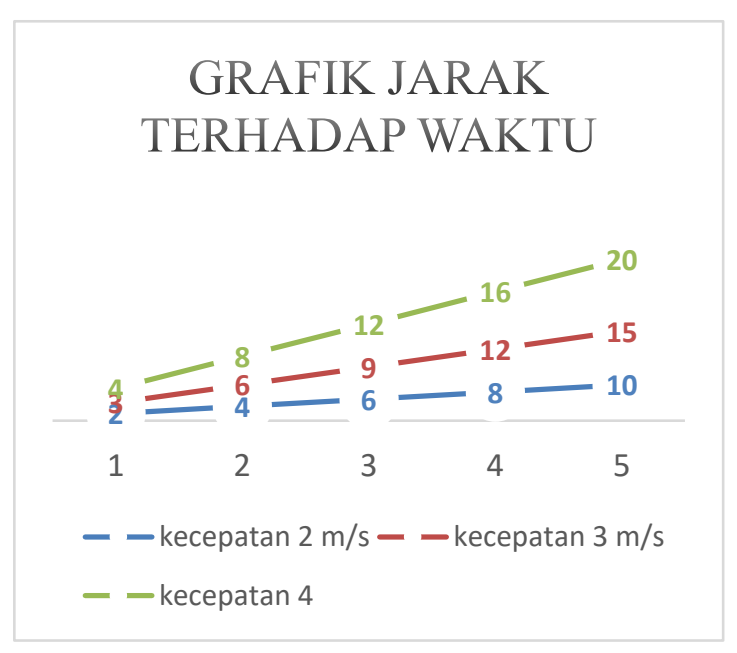

Grafik 1. Grafik jarak terhadap waktu

Dari hasil perbandingan antara perhitungan menggunakan virtual ticker timer dengan perhitungan manual mendapatkan hasil grafik yang sama. Sehingga dapat kita ketahui juga bahwa penggunaan emulator virtual ticker timer efektif digunakan oleh pendidik maupun peserta didik dalam pembelajaran materi gerak lurus.

Selain itu, didapat juga data bahwa besar kecepatan awal berpengaruh pada jarak yang ditempuh. Semakin besar nilai kecepatan awalnya maka, akan semakin besar pula jarak yang akan ditempuh.

Tetapi, media pembelajaran simulasi ticker timer ini masih mempunyai kelemahan atau kekurangan yaitu pengisian angka kecepatan atau percepatan yang masih terbatas dan tampilan yang masih kurang menarik serta tidak dapat merubah atau mengganti nilai frekuensinya.

Kelebihan melakukan percobaan langsung : (1) siswa merasakan secara langsung pengalaman tersebut. Menurut Jumaini dalam Royani bahwa praktikum yang dilakukan di laboratorium memiliki manfaat dan pengalaman yang cukup besar bagi siswa dalam ketiga ranah pembelajaran. Pada ranah kognitif, praktikum di laboratorium memberikan manfaat dalam membantu pemahaman siswa. Pada ranah afektif, praktikum dapat melatih sikap ilmiah siswa. Pada ranah psikomotorik, pelaksanaan praktikum dapat melatih keterampilan siswa dalam menggunakan alat dan bahan, (2) melibatkan siswa secara aktif dalam memperoleh kesempatan pembelajaran, (3) terjalinnya komunikasi antara siswa dengan siswa, dan siswa dengan guru, sehingga melatih komunikasi siswa, (4) siswa menjadi lebih terampil, dan (5) praktikum secara langsung dianggap tidak membosankan. Menurut Royani mengatakan bahwa siswa menganggap bahwa pembelajaran berbasis laboratorium lebih menyenangkan, tidak membosankan dan lebih menarik karena dapat mengetahui dan mengalami secara langsung mengenai materi yang didapatkan.

Langkah- langkah untuk menggunakan simulasi ticker timer yaitu 
pada bagian bawah ditampilan ticker timer terdapat kolom untuk mengisi angka kecepatan dan percepatan mobil tersebut. Dan terdapat tombol play di bagian bawah untuk menjalankan atau memulai simulasi ticker timer. Serta terdapat tombol grafik di bagian bawah samping kanan tombol play berfungsi untuk mengganti grafik yang digunakan sesuai kebutuhan adapun grafiknya yaitu jarak terhadap waktu dan kecepatan terhadap waktu. Selanjutnya dapat mengunakan simulasi ticker timer dengan cara pertama mensetting grafik yang diinginkan, kemudia mengisi kolom kecepatan dengan angka yang diingkan. Kemudian klik tombol play, dan otomatis mobil akan berjalan dengan kecepatan atau percepatan yang tadi dimasukan. Kemudian kalian dapat mengamati hasil grafik dari percobaan tersebut.

\section{PENUTUP}

\section{A. Kesimpulan}

Berdasarkan penelitian di atas dapat disimpulkan bahwa: 1) Simulasi virtual gelak lurus mudah digunakan dan dapat digunakan offline. 2) Dari hasil percobaan bahwa kecepatan berpengaruh terhadap jarak tempuh semakin besar kecepatan awal maka semakin besar pula jarak yang ditempuh. 3) Simulasi virtual gerak lurus ini effektif untuk dijadikan media pembelajaran fisika di sekolah.

\section{B. Saran}

Saran yang dapat disampaikan kepada pendidik sebaiknya pendidik dapat memperhatikan lagi apabila ada peserta didik yang kurang paham dalam memahami materi yang dipelajari. Selain itu, sebaiknya pendidik lebih bisa menggunakan alat peraga lainnya dalam memberikan penerapan materi Gerak Lurus.

\section{PUSTAKA}

[1] Nana. (2018). Implementasi Model POE2WE Dengan Pendekatan Saintifik Dalam Pembelajaran Gerak Lurus di SMA. SNPS. 19.

[2] Ayunita, Tania Azizah, dkk. (2014). Pengembangan Perangkat Laboratorium Fisika Virtual Berbasis Masalah Pada Alat Praktikum Ticker Timer. Semarang: Universitas Malang.

[3] Nana., Sajidan., Akhyar. M., dan Rochsantiningsih, D. (2013). Pengembangan Pembelajaran Fisika SMA Melalui Elaboration Write And Evaluation (EWE) dalam Kurikulum 2013. Surakarta. Universitas Sebelas Maret. Jurnal FKIP UNS. Hal 1-8.

[4]Nana. (2018). Model Prediction, Observation, Explanation, Elaboration, Write dan Evaluation (POE2WE) Aternatif Pembelajaran Fisika di Era Revolusi Industri 4.0.

[5] Nisa, Choirun, dkk. (2014). Perancangan Instrumentasi Pengukur 
Waktu Dan Kecepatan Mengunakan DtSense Infrared Proximity Detector

Untuk Pembelajaran Gerak Lurus Beraturan. JPFA. Vol 4.

[6] Mujadi, dkk. (1994).Materi Pokok Desain Dan Pembuatan Alat Peraga IPA. Jakarta: Universitas Terbuka, Depdikbud.

[7] Ranchman, Robbie Nur, dkk. (2016). Pengembangan Simulasi Gerak Lurus untuk Pelajaran Kelas X. ISBN. Vol 1.

[8] Sobari, Ahmad dan Imam Sucahyo. (2016). Pengembangan Alat Peraga Ticker Timer Sebagai Alat Peraga Pembelajaran Fisika Pokok Bahasan Gerak Lurus. JIPF. Vol.05: 2-3.

[9] Wardani, A. K., dkk. (2013). Tinjauan Ulang Materi Ajar Gerak Lurus Beraturan Melalui Percobaan Gravity Current Dalam Skala Laboratorium. ISSN. Hal. 1. 